\title{
PROBLEMAS DA OBRA DE DOSTOIÉVSKI NO ESPELHO DA CRÍTICA SOVIÉTICA E ESTRANGEIRA
}

\section{PROBLEMS OF DOSTOIÉVSKY'S WORK IN THE MIRROR OF THE SOVIETIC AND FOREIGN CRITICISM}

\author{
Sheila Vieira de Camargo Grillo \\ Universidade de São Paulo, São Paulo, São Paulo, Brasil \\ sheilagrillo@uol.com.br
}

\begin{abstract}
Resumo: Este artigo objetiva examinar a recepção de POD (Problemas da Obra de Dostoiévski, 1929) na crítica soviética e estrangeira dos anos 1920 e 1930, à luz dos conceitos de fundo aperceptível do destinatário do discurso e horizonte valorativo. Para isso, foram reunidas resenhas e menções a POD, localizadas em bibliotecas e livrarias russas, que foram aqui traduzidas e analisadas. Os resultados da pesquisa apontaram: o tom dominante da crítica soviética foi "desmascarar" a filosofia idealista sob uma roupagem sociológica; as análises estilísticas foram no geral muito bem avaliadas; a tese sobre a polifonia dos romances de Dostoiévski é o ponto mais polêmico na recepção de POD; apontou-se a ocorrência de uma pesquisa formal dos procedimentos de criação de Dostoiévski, com incursões no campo da elucidação sociológica.
\end{abstract}

Palavras-chave: Problemas da Obra de Dostoiévski; Recepção; Resenhas; Tradução

\begin{abstract}
This article aims to examine the reception of PDW (Problems of Dostoiévsky's work, 1929) in the sovietic and foreign criticism in the 1920s and 1930s based on the concepts of apperceptive background of responsive understanding and valorative horizon. For this purpose, it was collected reviews and mentions to PDW in Russian libraries and bookstores, that were translated and analysed in the article. The results of the research indicated: the dominant view in the sovietic criticism was to "unmask" the idealistc filosophy under a sociological appearence; the stylistic analysis were in general well appreciated: Bakhtin is considerated a philosopher of the culture and of the dialogue: the thesis about the poliphony of the Dostoyevsky's novels is the most controversial aspect in the reception of PDW; it was indicated the ocurrence of a formal research in the Dostoyevsky's formal procedures, with incursions in the champ of sociological elucidation.
\end{abstract}

Keywords: Problems of Dostoyevsky's Work; Reception; Review; Translation 
O primeiro livro publicado por Bakhtin foi Problemas da Obra de Dostoiévski ${ }^{1}$ (doravante POD) em $1929^{2}$, trabalho que ficou mundialmente conhecido após sua segunda edição em 1963 com o título Problemas da Poética de Dostoiévski (doravante PPD) e que não para de produzir reedições e traduções. Em 2000, saiu o volume II de "M. M. Bakhtin. Obras Reunidas", (BAKHITN, 2000), organizado por Serguei Botcharóv e Leontina Miélikhova, com a edição de 1929 e materiais de arquivo. Em 2017, (BAKHTIH, 2017 a e b), vieram à luz na Rússia duas novas reedições, ambas formadas simultaneamente pelos textos de 1929 e 1963. O interesse, até o momento, recorrente por esses textos e a complexidade dos conceitos neles desenvolvidos (sobretudo, a meu ver, o de polifonia) motivou o objetivo de leitura e tradução, ao público brasileiro, de parte da recepção do livro de 1929 em resenhas publicadas por autores soviéticos logo após o seu aparecimento, bem como em resenhas e livros publicados no exterior e elencados por Botcharóv e Miélikhova no volume II das "Obras Reunidas". Nossa hipótese é que a análise dessa recepção (parcial) pela crítica pode nos revelar os impasses da compreensão, bem como o fundo aperceptível do destinatário do discurso e o horizonte valorativo (VOLOCHINOV, 2018[1929]; MEDVIÉDEV, 2012[1928]) de POD.

O fundo aperceptivo de percepção aparece em obras de Bakhtin e do Círculo nos anos 1920, 1930 e 1950 para designar a concepção que o locutor faz dos conhecimentos de dado campo da cultura, das convicções, dos valores, das preferências, das antipatias presumidas em seu destinatário, concepção que exercerá influência, fixará limites e exercerá pressões sobre o enunciado do locutor. O horizonte valorativo é constituído pelo conjunto de interesses e valores, sempre em processo de formação, de um determinado grupo social ${ }^{3}$.

Nossa exposição começará pela tradução e análise da recepção soviética de POD e, em seguida, abordará a crítica estrangeira.

\section{POD e a crítica soviética}

POD saiu em junho de 1929, quando Bakhtin já se encontrava em prisão domiciliar. Em 22 de julho 1929, Bakhtin recebeu a pena de 5 anos de campos de concentração (kontseláguer), que foram transformados em exílio em Kustanái, para o qual Bakhtin partiu em março de 1930. Nos comentários às "Obras Reunidas" (2000), Botcharóv e Miélikhova informam que, entre junho de 1929 e março de 1930, saíram 6 resenhas sobre POD, das quais 3 podem ser consideradas artigos.

A primeira delas foi escrita por N. Ia. Berkóvski (Lituânia, 1901- Leningrado, 1972), que fez seu doutoramento na Universidade de Petrogrado entre 1927 e 1930, sob a orientação de Víktor Jirmúnski, este conhecido integrante do grupo de formalistas russos de Leningrado. A partir dos anos 1930, foi professor em diversas instituições de ensino superior de Leningrado e publicou muitas obras sobre teatro russo e romantismo alemão. A seguir, traduzimos a resenha sobre POD:

\footnotetext{
${ }^{1}$ Título provisório. A palavra russa "tvórtchesvo" pode significar o conjunto de trabalhos de um autor (obra) ou o processo de criação de sua obra.

2 O material analisado neste artigo foi coletado durante estágio de pesquisa na Rússia, com apoio Fapesp, e faz parte de estudo para a tradução em curso de POD.

${ }^{3}$ Considerando que esses conceitos bakhtinianos já são bem conhecidos do público brasileiro e que o material a ser analisado é extenso, neste artigo não nos extenderemos mais na fundamentação teórica, que tomaria espaço da tradução e análise das resenhas soviéticas e estrangeiras, essas sim pouco ou nada acessíveis ao nosso leitor.
} 


\section{M. Bakhtin. Problemas da Obra de Dostoiévski, 1929, L., Priboi. $^{4}$}

Neste livro há uma parte inteira de linguística. Ou melhor: a parte na qual é tratado o problema da palavra em Dostoiévski é filosófico-linguística.

Partindo da observação do discurso ${ }^{5}$ cotidiano, Bakhtin toma o material do discurso literário sob um ponto de vista interessante.

Normalmente estuda-se o discurso em seu direcionamento para o objeto; mais raramente estuda-se o discurso do ponto de vista de uma relação especial do falante com o objeto, para o qual o enunciado é direcionado.

Bakhtin não analisa o falante isoladamente; nele o falante entra não como "Eu", mas como "Nós"; Bakhtin considera a posição social do portador da palavra, e de fato tenta apresentar o reflexo dessa posição social. É como se o portador da palavra pressentisse o oponente ou o polemista, e pressentisse a palavra alheia, a outra avaliação, ele antecipa a ressonância social do seu discurso. Ver como seu discurso será percebido por diferentes destinatários sociais, em diferentes setores sociais, pode revelar sinais claros dessa antecipação e desse pressentimento no discurso pronunciado.

O personagem de Dostoiévski fala com um olhar nervoso voltado para o "público", para o coletivo; como esse coletivo é multiestratificado, não há uma reação homogênea e estável no discurso do personagem. Disso o entrecortamento dos enunciados verbais dos personagens por meio de entonações com múltiplas características: de rebate, de insegurança, ora de autodefesa orgulhosa, ora de recuo covarde, mas necessariamente com o peito inflado, para novamente, depois de um minuto, assumir a posição de atacante.

Nesse plano ocorre a análise bem-sucedida de Bakhtin sobre o discurso de Mákar Diévuchkin, Goliádin e outros. De fato, Bakhtin consegue revelar a semântica social desses discursos, consegue ser mais sutil e mais necessário em sua pesquisa, do que seus predecessores que se ativeram ao método de registro abstrato formal.

Não é só o "meio" do personagem de Dostoiévski que é instável; o próprio personagem é instável. É como se o meio invadisse o psiquismo do personagem e motivasse a destruição, a polêmica, a confusão dos auto enunciados.

Bakhtin explica essa apresentação do psiquismo e do discurso do personagem pelas particularidades da época capitalista no momento de sua primeira evolução: o choque de diferentes esferas e valores sociais, que existia de modo desordenado antes do capitalismo, gerou esse personagem e esse discurso vacilante, sem uma orientação social firme.

Bakhtin escreve no prefácio:

"Na base da presente análise está a convicção de que toda obra literária é imanente e internamente sociológica. Nela entrecruzam-se forças sociais vivas, cada elemento da sua forma é atravessado por avaliações sociais vivas".

Como exemplo de sociologização das questões, está totalmente claro que Bakhtin percebe as tarefas de modo sociológico, ao interpretar o material literário com a consideração das condições socioeconômicas: enquanto material, tanto o personagem quanto o discurso não são outra coisa.

Bakhtin justifica que essa sociologização não é suficientemente detalhada.

Contudo, mesmo que ela fosse detalhada, não haveria salvação. A sociologização do material tem o valor de um comentário real, não mais do que isso.

Toda a questão está em submeter a estrutura integral a uma explicação social, e, na estrutura, o personagem com seu discurso e qualquer outro material ocupam um lugar secundário.

Essas tentativas são visíveis em Bakhtin. Após Kaus, Bakhtin explica a “polifonia” dos romances de Dostoiévski pela polifonia da cultura capitalista e da sociedade e assim por diante. Estabelece-se uma analogia entre a estrutura do objeto artístico e a estrutura de dado período socioeconômico. O método é ingenuamente arbitrário, apesar de ele também ser praticado em algumas outras pesquisas.

O que é mais nefasto no livro de Bakhtin são as suas afirmações completamente inconsistentes e com fundamentos essencialmente errados sobre a pretensa "polifonia" do romance de Dostoiévski. Segundo Bakhtin, nos romances de Dostoiévski está ausente a "direção" autoral, pois os planos plenivalentes ("vozes") das consciências individuais de modo algum são reduzidos à consciência unitária do autor; nesse romance, cada voz vive isolada, e, como resultado, o romance é uma espécie de plurivocalidade, "polifonia", que não é de modo algum unificada pela voz autoral única.

Na realidade, o romance de Dostoiévski é unificado ao extremo justamente pelo pensamento autoral, pelo sentido autoral; o autor julga as "vozes" dos personagens por meio de uma revelação exemplar do enredo;

\footnotetext{
${ }^{4}$ Originalmente publicada na revista Zviézd, número 7, 1929, e a tradução é minha.

5 Em todos os lugares em que aparece a palavra portuguesa "discurso", estamos traduzindo a palavra russa "rietch", a mesma que ocorre em "interação discursiva" e os "gêneros do discurso", por exemplo. Outras possibilidades de tradução seriam "fala" ou "linguagem".
} 
para o final do enredo, experimenta-se ("provoca-se" na expressão bem sucedida de Bakhtin) tanto o mundo do personagem quanto a sua visão de mundo, a sentença autoral é pronunciada em primeira instância.

A ideia mal sucedida de "polifonia" destroi toda a construção de Bakhtin. Do livro ficam apenas algumas teses sociolinguísticas particulares.

Para entendermos a organização dessa resenha é preciso saber que POD (1929) é dividido em duas partes: a primeira chama-se "O romance polifônico de Dostoiévski: apresentação do problema", e a segunda, "A palavra/discurso em Dostoiévski: ensaio de estilística" ${ }^{6}$. A resenha de Berkóvski começa por uma avaliação positiva da segunda parte do texto bakhtiniano, considerada por ele de natureza "filosófico-linguística" e que vai em parte ao encontro, a nosso ver, da recepção da obra por linguistas brasileiros que normalmente se interessam pelas relações dialógicas, pela palavra bivocal, pela classificação dos tipos de discurso e dos diversos tipos de palavra bivocal (polêmica aberta e velada, paródia etc.). Berkóvski descreve as duas principais direções da metodologia de Bakhtin: por um lado, a relação do falante com o objeto presente no enunciado, e, por outro, o diálogo interno do locutor com seus interlocutores no interior do seu enunciado. Evidentemente essas duas dimensões não são isoláveis, mas constituem aspectos de um mesmo fenômeno.

$\mathrm{Na}$ parte final da resenha dedicada à primeira parte de POD, Berkóvski rejeita a tese central de Bakhtin sobre a inovação essencial do romance de Dostoiévski: a sua polifonia ${ }^{7}$. Segundo Botcharóv e Miélikhova (2000), essa posição sintetiza e antecipa uma reação à tese bakhtiniana que perdura até os dias atuais. No volume 2 das "M.M. Bakhtin. Obras reunidas" (2000), reproduz-se uma carta de Berkósvki de 18/01/1956, conservada no arquivo pesssoal de Bakhtin, endereçada a este em resposta a uma carta anterior de Baktin. Berkóvski agradece pelos comentários feitos por Bakhtin sobre um livro organizado por ele e acrescenta: "É claro que você é lembrado e conhecido por todos os que procuram livros bons e verdadeiros." (2000, p. 514) e o incentiva ainda a publicar novas obras. Apesar de não mencionar a resenha de POD, Botcharóv e Miélikhova (2000, p. 513) consideram que, nesta carta, Berkóvski "decididamente retifica sua resenha".

A segunda resenha saiu em 08 de agosto de 1929, no jornal Utchítelskaia Gaziéta [Jornal Pedagógico], que começou a ser editado em 1924, em Moscou, pelo Ministério da Educação da União Soviética e pelo sindicato dos trabalhadores da educação, e continua a ser publicado até os dias de hoje. Ela foi escrita pelo crítico literário Arkádi Glagólev e está abaixo traduzida:

\section{M. Bakhtin. Problemas da obra de Dostoiévski. Ed. Pribói, Leningrado, 1929. p. 244. Tiragem 2.000, Preço 2 rublos e 50 koniéek.}

M. Bakhtin propõe a tarefa de revelar a "inovação revolucionária (de Dostoiévski) no campo do romance como forma artística". O autor analisa essa inovação artística de Dostoiévski exclusivamente no plano dos problemas teóricos, deixando o aspecto histórico fora de sua exposição, muito embora tenha consciência de toda a importância deste último.

Obviamente a ausência de análises históricas diminui muito a importância do livro e nos força a considerar que o problema da inovação artística de Dostoiévski apresentado no livro está ainda longe de ser resolvido em sua integralidade.

Apesar de tudo, o livro de Bakhtin não é de todo sem interesse.

\footnotetext{
6 Essa segunda parte corresponde ao capítulo 5 "O discurso no romance" de "Problemas da poética da Dostoiévski” (1963)

${ }^{7}$ Durante a apresentação desta pesquisa no 21 INPLA (PUC-SP, 2018), Tatiana Bubnova, tradutora da obra bakhtiniana para o espanhol, comentou que as críticas de Berkóvski poderiam ser explicadas pela polêmica entre o Círculo de Bakhtin e os formalistas russos, entre os quais estava Jirmúnski, o orientador de doutorado do resenhista.

${ }^{8}$ Tradução minha.
} 
A análise teórica de nosso autor, diferentemente da teorização de muitos "dostoiévskianos" do campo idealista, não está pendurada no ar, não está privada de sociologismo.

Na base da presente análise - escreve Bakhtin - está a convicção de que toda obra literária é interna e imanentemente sociológica. Nela entrecruzam-se forças sociais vivas. Cada elemento da sua forma é atravessado por avaliações sociais vivas. Em razão disso, uma análise puramente formal deve tomar cada elemento da estrutura artística, como um ponto de refração de forças sociais vivas...

Essa declaração de Bakhtin não fica sem fundamento.

As principais conclusões que podem ser tiradas do trabalho de Bakhtin não estarão em contradição com aquelas decorrentes dos trabalhos de V. Pereverzev e Otto Kaus*; sobretudo este último é muito citado por Bakhtin.

Segundo Bakhtin, Dostoiévski "é o criador do romance polifônico", do romance "multiplanar" e "multivocal". Bakhtin vê as particularidades principais desse tipo de romance no fato de que o agente não é apenas "objeto da palavra do autor", mas também "sujeito da própria palavra imediatamente significante" (p. 9). "O romance de Dostoiévski é lógico" (p. 27). "O autor não contrapõe a consciência sobre si, que o contém e o fecha do exterior, à autoconsciência de cada personagem em separado, mas à multiplicidade de outras consciências, que se revelam na interação tensa com ele e entre si” (p. 242-3). Bakhtin faz uma série de observações curiosas, as quais concretizam sua posição geral. Por falta de espaço, apontaremos apenas aquelas observações isoladas, que são interessantes de um ponto de vista sociológico.

Por exemplo, é curiosa a situação característica do personagem nos romances de Dostoiévski "Para Dostoiévski não é importante como o personagem é no mundo, mas como o mundo é para o personagem e como ele é para si próprio” (p. 53); “... tudo o que normalmente serve ao autor para a criação de uma imagem fixa e estável do personagem - 'que é ele' - em Dostoiévski torna-se objeto de reflexão do próprio personagem ...” (p. 54). Todas essas particularidades artísticas dos personagens na obra de Dostoiévski correspondem plenamente e podem ser explicadas pela interpretação marxista da essência social dos personagens de Dostoiévski, entendidos como representantes da intelliguentsia pequeno burguesa urbana e um pouco marginal.

Encontramos muitos aspectos interessantes na análise da estilística de Dostoiévski feita por Bakhtin. É impossível não concordar com o autor de que "o estilo verbal determinado pela antecipação tensa do estilo alheio" é extremamente característico da obra de Dostoiévski (p. 137). "O olhar para a palavra social alheia"; o cuidado "com a seleção e a resolução da pergunta 'quem sou eu' e 'com quem estou",; a tendência exacerbada a “encontrar a própria voz e sua orientação entre outras vozes ..."; a ausência nas obras de Dostoiévski "de uma palavra que seja uma vez e para sempre finalizadora, acabadora e determinante", tudo isso é adequado para uma interpretação sociológica do estilo de Dostoiévski, enquanto estilo da intelliguentsia urbana solitária, marginal e em conflito social.

Bakhtin também compreende corretamente o sentido do estilo de Dostoiévski. Segundo Bakhtin, é preciso procurar as razões e os fatores "que tornaram possível a construção do romance polifônico" não na "vida pessoal" de Dostoiévski, mas no "mundo objetivo social" (p. 42-3). O estilo do romance polifônico de Dostoiévski, para Bakhtin, "é a expressão profunda da desorientação social da intelliguentsia raznotchínetz" (p. 241).

Desse modo, é verdade que, ao qualificar sociologicamente a obra de Dostoiévski como produto artístico da intelliguentsia pequeno burguesa urbana desorientada pelo capitalismo, Bakhtin admite, entretanto, um grande erro, quando propõe que, apesar do caráter alheio e da inadmissibilidade para nossa contemporaneidade do "conteúdo ideológico" de Dostoiévski, a "construção" desse mundo (isto é, a forma da obra de Dostoiévski) "permanece" para nós "não só como documento, mas também como modelo". (p. 51)

De um ponto de vista marxista, essa ruptura entre a "forma" e o "conteúdo" é completamente inadmissível (além disso, a afirmação de Bakhtin é incompreensível, pois ele próprio constata a sua "ligação inseparável"). As particularidades artísticas de Dostoiévski foram geradas a partir das particularidades sociais da sua classe, cuja psicologia se distingue profundamente do proletariado; por isso, o estilo de Dostoiévski não pode servir como "modelo" para nossa literatura ficcional contemporânea.

Se ler o livro de modo crítico, o professor de língua e literatura pode extrair para si muita coisa útil para o esclarecimento do estilo de Dostoiévski.

\footnotetext{
* O. Kaus é o autor do trabalho "Dostoiewski und sein Schicksal", único livro sobre Dostoiévski no Ocidente, que se aproxima do marxismo e analisa a obra de Dostoiévski como a expressão mais forte do espírito do capitalismo.

${ }^{9}$ Posição social na Rússia czarista do século XIX, ocupada por indivíduos que, apesar de provindos de classes desfavorecidas, desempenhavam atividades intelectuais e normalmente defendiam ideologias democráticas.
} 
A segunda resenha faz, no geral, uma avaliação positiva do livro em razão do seu caráter sociológico. Apesar disso, sua primeira observação destaca a limitação do estudo em virtude da ausência de uma abordagem histórica, o que é admitido pelo próprio Bakhtin logo nas primeiras linhas do prefácio a POD:

\begin{abstract}
Este livro limita-se a abordar apenas os problemas teóricos da obra de Dostoiévski. Tivemos que excluir todos os problemas históricos. No entanto, isso não significa que consideramos correto e normal esse modo de análise. Ao contrário, acreditamos que todo problema teórico deve ser necessariamente orientado em uma perspectiva histórica. Entre as abordagens sincrônica e diacrônica deve haver uma ligação ininterrupta e uma convencionalidade recíproca forte. Contudo, esse é um ideal metodológico. Na prática, ele não é sempre realizável. (BAKHTIN, 1929, p. 3)
\end{abstract}

Essa crítica de Arkádi Glagólev é interessante por assinalar aquele aspecto que motivará a maior alteração na segunda edição em 1963, quando Bakhtin inclui, no penúltimo capítulo, as questões de poética histórica, apontando as origens do romance polifônico nos diálogos socráticos, na sátira menipéia, em Dante Aleghieri etc. A pesquisa sobre poética histórica estará no centro da atenção de Bakhtin durante toda a década de 1930, quando ele escreve seus trabalhos sobre o gênero romance e sobre a obra de François Rabelais.

O caráter sociológico da forma artística de Dostoiévski desenvolvido por Bakhtin é o principal destaque da resenha de Arkádi Glagólev, que busca aqueles fragmentos mais ilustrativos dessa abordagem e a considera correta. No entanto, durante a análise dessa resenha, Botcharóv e Miélikhova (2000), nos comentários ao volume II das "M.M. Bakhtin. Obras Reunidas", considera que Bakhtin, ao colocar seu texto na linguagem da época e dar uma roupagem sociológica ao seu texto, colocou-se nas mãos da crítica dominante que posteriormente chamou essa análise de "sociologismo vulgar". Em outras palavras, Botcharóv considera ser a abordagem sociológica apenas uma "fachada", motivada pelo fundo aperceptível de percepção e pelo horizonte valorativo da crítica dominante à época.

A segunda restrição de Arkádi Glagólev ao livro de Bakhtin é que este afirma o caráter modelar da forma artística de Dostoiévski para a época, porém esta foi elaborada no contexto "da intelliguentsia pequeno burguesa urbana desorientada pelo capitalismo" e, portanto, não serve como modelo para a literatura de uma sociedade socialista governada pelo proletariado. $\mathrm{O}$ valor da obra é medido em função de sua adequação ao marxismo soviético hegemônico nos anos 1920.

A avaliação final da resenha valoriza sobretudo as análises bakhtinianas sobre o estilo de Dostoiévski, contidas na segunda parte da obra de 1929, posição presente também na resenha anteriormente analisada. A esfera de circulação do jornal, voltado para professores de língua e literatura russa, reflete-se no último parágrafo da resenha, que recomenda a obra para professores de língua e literatura russa com base na sua utilidade para a compreensão do estilo de Dostoiévski.

A terceira resenha foi escrita por Iuda Gróssman-Róchin (Ucrânia, 1883-Moscou, 1934) $)^{10}$, ilustre anarquista e depois revolucionário bolchevique com intensa atividade política que, nos anos 1920, integrou-se no sistema soviético e se tornou um crítico literário da Associação Russa de Escritores Literários, com publicações regulares nos periódicos Oktiábr [Outubro], Petchát i Revoliútsiia [Imprensa e Revoluções] e Bilóe [Passado]. Sua resenha ${ }^{11}$, que abre o número 18 do periódico Na literatúrnom postú [No posto literário], é um pequeno artigo de 6 páginas com colunas duplas e, devido a sua extensão, não será possível traduzi-la em sua integralidade aqui. Faremos uma análise de sua organização e traduziremos os trechos mais ilustrativos de sua abordagem.

\footnotetext{
${ }^{10}$ Fonte: https://biography.wikireading.ru/44352 Acesso em 15 jun. 2018.
}

${ }^{11}$ Os fragmentos a seguir transcritos foram por mim traduzidos. 
A resenha começa com uma longa citação de um manuscrito de Marx, no qual ele analisa a relação entre o encanto da arte grega antiga e a sociedade grega antiga que ele chama de imatura e pouco desenvolvida. Gróssman-Róchin considera que "não se pode depreender a visão de mundo de Marx no campo da arte - até mesmo nos limites estreitos do tema abordado - com base nesse fragmento" (1929a, p. 5) e interpreta que, no excerto citado, Marx se opõe ao agnosticismo na arte, isto é, que apenas a ciência tem a capacidade de previsão. Em seguida, Gróssman-Róchin prossegue atacando abordagens idealistas e analisando a coletânea de artigos de Piótr Lavróv ${ }^{12}$ e termina as duas primeiras páginas da resenha com a seguinte afirmação:

De modo cada vez mais frequente, encontramos fenômenos extremamente disformes: ou o conhecimento sobre o caráter convencional da arte aparta-se de uma orientação objetiva (a orientação é transferida para a esfera da percepção) ou a orientação e a realidade separam-se da gênese produtora de classe, e então temos diante de nós um pragmatismo burguês típico (1929a, p. 6)

Com essa afirmação, que faz uma espécie de balanço geral da crítica literária de um ponto de vista marxista, Gróssman-Róchin termina a primeira parte da resenha e logo em seguida dá a notícia do lançamento do livro de Bakhtin sobre Dostoiévski. Está claro que ele julgará, se a abordagem de Bakhtin é genuinamente marxista. A avaliação começa com uma apreciação positiva - "No livro de Bakhtin, encontra-se uma série de observações interessantes e corretas, sobre as quais é preciso falar em relação à avaliação da obra de Dostoiévski" - e logo em seguida passa para a seguinte análise:

\begin{abstract}
Neste artigo interessamo-nos pela seguinte questão: em que medida o autor aproximou-se cientificamente da compreensão da gênese de classe e da orientação da obra de Dostoiévski? O autor solenemente nos certifica: 'Na base da presente análise está a convicção de que qualquer obra literária é interna e imanentemente sociológica. Nela cruzam-se forças sociais vivas, cada elemento da sua forma é atravessado por avaliações sociais vivas. É por isso que uma análise puramente formal deve tomar cada elemento da estrutura artística como um ponto de refração das forças sociais vivas, como um cristal artificial, cuja fronteira é construída e lapidada de tal modo a refratar determinados raios das avaliações sociais e refratálos sob determinado ângulo'.

Essa formulação é estranha, escorregadia e ambígua. O que ela quer dizer é incompreensível: 'uma obra literária é imanentemente sociológica'? Contudo, vejamos o que é ruim de todo: o autor fala sobre forças sociais, mas essas forças sociais figuram na qualidade de avaliações sociais, cujas imagenzinhas vimos em P. Lavróv. Entretanto, essa formulação pode provir de qualquer idealista, positivista, defensor de um ponto de vista 'valorador' (avaliativo). Aqui não há sobra do princípio marxista do conhecimento científico. (GRÓSSMAN-RÓCHIN, 1929a, p. 7)
\end{abstract}

Gróssman-Róchin começa com uma avaliação da afirmação bakhtiniana sobre o caráter sociológico da obra de arte, que é onde se poderia localizar uma abordagem materialista. No entanto, sua avaliação, como fica evidente no trecho acima, é que essa afirmação não garante o caráter marxista da obra e é ambígua. O resenhista prossegue em seu exame até chegar ao seguinte fragmento que ele considera a prova cabal do caráter idealista do trabalho de Bakhtin:

\footnotetext{
${ }^{12}$ Piotr Lavrovitch Lavróv (1823-1900) é um dos ideológos da "naródnitchestva", ideologia que defendia uma aproximação da intelliguentsia russa do século XIX com o povo, na busca de suas raízes e de seu lugar no mundo.
} 
Estamos convencidos de que o livro apaixonante e interessante escrito por Bakhtin é até bem capaz de seduzir 'pequeninos irmãos', pois o autor foi aprovado magnificamente na escola de como mascarar suas posições essencialmente idealistas em uma aparência de classe!.. (GRÓSSMAN-RÓCHIN, 1929a, p. 9)

"O enredo de aventuras, ao contrário, é precisamente uma roupa que se ajusta bem ao personagem e que ele pode mudar o quanto quiser. $\mathrm{O}$ enredo de aventuras opera não com o fato de que o personagem existe e ocupa um lugar na vida, mas com o fato de que ele não existe e de que, do ponto de vista de uma realidade presente, ele não é predeterminado e inesperado. O enredo de aventura não opera com situações presentes e estáveis - familiares, sociais, biográficas, ele se desenvolve contra elas. A situação de aventuras é aquela na qual pode se encontrar qualquer pessoa, tomada como ser humano. Além disso, o enredo de aventuras não utiliza qualquer localização social estável como forma que dá acabamento à vida, mas como 'situação'. Assim, o aristocrata do romance de bulevar não tem nada em comum com o aristocrata do romance socio-familiar. $\mathrm{O}$ aristocrata do romance de bulevar é uma situação na qual a pessoa se encontra. A pessoa age na roupagem do aristocrata, enquanto ser humano: atira, comete um crime, foge dos inimigos, supera obstáculos etc. Nesse sentido, o enredo de aventuras é profundamente humano. Todas as instituições sociais e culturais, corporações, classes e relações familiares são apenas situações, nas quais pessoas eternas e iguais podem encontrar-se. As tarefas ditadas pela natureza humana eterna, pela autopreservação, pela sede de vitória e de triunfo, pela sede de possuir, pelo sentimento de amor, determinam o enredo de aventura."

Finalmente Bakhtin abriu o jogo! Em Dostoiévski, a construção do enredo acaba elevando-se acima das relações de classe entre o latifundiário e o camponês, o proprietário e o proletariado! A existência real de classes é substituída pela categoria da 'possibilidade' de aventuras. Estamos lidando com as tarefas ditadas pela 'natureza humana eterna'! Verifica-se que 'em sua essência, todos os personagens de Dostoiévski encontram-se fora do tempo e do espaço, como dois seres sem limitações'! Eis em que consiste a tese do autor de que Dostoiévski toma os personagens fora da dimensão temporal! As cartas estão na mesa! Trata-se do avanço da natureza humana eterna, que está acima das relações entre 'latifundiário e o camponês, o proprietário e o proletariado'. Eis o famoso cristal, a aresta polida prodigiosamente, na qual algo é refletido! De fato, está astutamente mascarada a abordagem contra a compreensão materialista da arte. (GRÓSSMAN-RÓCHIN, 1929a, p. 10)

Após essa avaliação cabal de POD, Gróssman-Róchin termina sua resenha com as seguintes afirmações "os idealistas também ensinaram algo. Eles compreendem que não é possível vencê-los em uma luta aberta". (1929a, p. 10). Ao analisar essa resenha, Botcharóv e Miélikhova (2000) concluem que ela deu o tom fundamental da crítica na imprensa soviética até o início dos anos 1960.

A próxima resenha - quarta - é também um artigo, ainda maior do que o anterior, e foi publicada na revista Novii mir [Novo mundo], $\mathrm{n}^{\mathrm{o}}$. 10, p. 195-209, por Anatóli Vassílievitch Lunatchárski (1875-1933) ${ }^{13}$, político e ativista soviético, escritor, tradutor, crítico literário. Lunatchárski participou da Revolução Russa e ocupou importantes cargos na administração soviética, inclusive o de membro do Comissariado Popular da Educação, espécie de Ministério da Educação do governo soviético ${ }^{14}$. Uma cópia da resenha de Lunatchárski foi apresentada no dossiê ${ }^{15}$ que Bakhtin preparou para sua defesa de doutorado, como prova do reconhecimento do seu trabalho por uma autoridade da área. A resenha começa com uma avaliação geral da natureza da obra de Bakhtin: "Em seu interessante livro,

\footnotetext{
13 Todos os excertos a seguir transcritos são traduções minhas.

${ }^{14}$ Disponível em: http://to-name.ru/biography/anatolij-lunacharskij.htm. Acesso em 03/07/2018.

${ }^{15}$ Soubemos disso ao trabalharmos, no primeiro semestre de 2018, no arquivo pessoal de M. M. Bakhtin que se encontra no "Instituto das Literaturas do Mundo Im. Górkogo" (IMLI-Moscou), onde ele defendeu sua tese "Rabelais na história do realismo".
} 
M.M. Bakhtin escolhe em especial só alguns problemas da obra de Dostoiévski e os aborda majoritaria e até quase exclusivamente a partir da forma dessa obra". (LUNATCHÁRSKI, 1929, p. 195)

Lunatchárski considera que o trabalho de Bakhtin analisa aspectos formais da obra de Dostoiévski, que são em seguida definidos:

\begin{abstract}
os procedimentos formais da obra, dos quais trata Bakhtin em seu livro, surgem de um fenômeno fundamental, que ele considera particularmente importante em Dostoiévski [...] a plurivocalidade de Dostoiévski. (LUNATCHÁRSKI, 1929, p. 195)

Eu sou inclinado a concordar com Bakhtin, que talvez fosse próprio de Dostoiévski - se não na realização acabada do romance, ao menos no seu projeto inicial e no seu desenvolvimento gradual - um plano construtivo antecipadamente colocado e, portanto, estamos diante, de fato, de um tipo polifônico de composição, entrelaçando personalidades absolutamente livres. (LUNATCHÁRSKI, 1929, p. 196)
\end{abstract}

Lunatchárski identifica o procedimento central apontado por Bakhtin e expressa sua concordância com ele, apesar de observarmos várias ressalvas em sua resenha, decorrentes, a meu ver, da dificuldade de entender como se realiza efetivamente a polifonia. Um pouco antes ele já havia afirmado "se esses romances são polifônicos no sentido acima apontado, é difícil entender em que consiste" (LUNATCHÁRSKI, 1929, p. 196). A seguir, o resenhador continua a manifestar sua concordância com as teses de Bakhtin: "Considero também necessário enfatizar a verdade de outra afirmação: M. M. Bakhtin assinala que efetivamente as vozes de todos os que desempenham um papel essencial no romance representam 'convicções' ou 'pontos de vista sobre o mundo"”. (LUNATCHÁRSKI, 1929, p. 196). A esse respeito, Lunatchárski comenta o caráter profundamente ético dessas vozes-ideias que se realizam em profundo diálogo.

Ao introduzir a presença de uma abordagem sociológica no trabalho de Bakhtin, Lunatchárski volta a grifar o aspecto formal da obra de Bakhtin:

Apesar de em seu livro M. M. Bakhtin assumir principalmente o ponto de vista de uma pesquisa formal dos procedimentos de criação de Dostoiévski, ele não evita algumas incursões no campo da sua elucidação sociológica. (LUNATCHÁRSKI, 1929, p. 196).

Essas incursões no campo sociológico são analisadas a partir das citações de Otto Kaus feitas por Bakhtin, nas quais se afirma que Dostoiévski refletiu em si a enorme desorganização ética do capitalismo. Essa abordagem, Lunatchárski considera "muito boa e verdadeira" (LUNATCHÁRSKI, 1929, p. 197).

Para introduzir a discussão do conceito de polifonia, Lunatchárski propõe realizar uma breve comparação entre o polifonismo de Dostoiévski com o de outros escritores. Em primeiro lugar, Lunatchárski avalia que a obra de Shakespeare é "extremamente polifônica" (1929, p. 198), pois este soube produzir personagens independentes de si e sem qualquer relação com suas vivências pessoais e que Shakespeare também refletiu em sua obra um mundo dilacerado pelo capitalismo nascente na Inglaterra. Ao encerrar a abordagem de Shakeaspeare, Lunatchárski retoma Dostoiévski:

[...] diferentes representações da comunhão [sobórnosti], da harmonia, apesar de metafísica e do além, são próprias de Dostoiévski. Dostoiévski não é só um espelho, com paixão concentrou-se no caos constante da vida e nos tormentos do seus conflitos. Esses conflitos são doentios para ele, que internamente desejaria pacificálos e, se algo ocorreu, ele em um grau muito maior do que Shakespeare e de modo muito mais acentuado ocupa-se disso. É verdade que ele faz isso sem sucesso. (LUNATCHÁRSKI, 1929, p. 200). 
Em seguida, o resenhador ao abordar a obra Balzac (que não teria sido citado por Bakhtin, mas que era admirado por Dostoiévski, sendo inclusive traduzido por este) argumenta ter sido Balzac também polifônico:

O parentesco de Balzac com Shakespeare não está apenas na diversidade notável de matizes no mundo circundante de Balzac à época do estabelecimento inicial do regime capitalista mais ou menos acabado depois da tempestade da grande revolução, mas também no polifonismo no sentido da liberdade e das 'vozes' plenivalentes. (LUNATCHÁRSKI, 1929, p. 200).

Embora considere que Balzac não tenha sido um pensador tão poderoso quanto Dostoiévski, Lunatchárski afirma que aquele antecedeu este na criação do romance polifônico e, consequentemente, Bakhtin não tinha razão ao afirmar que Dostoiévski foi o inventor desse gênero.

Após a avaliação do polifonismo em Shakespeare e Balzac, Lunatchárski abre uma segunda seção em sua resenha com o propósito de entender a presença de Dostoiévski em seus romances e coloca uma série de questões sobre como entender a sua polifonia:

[...] por que é preciso considerar que existe uma significativa parcela de verdade na afirmação de Bakhtin de que é difícil formular conclusões acabadas sobre Dostoiévski, se não como teórico e jornalista, mas justamente como beletrista e romancista? Por que seus romances causaram a impressão também em Kaus de ‘disputas não acabadas'? Por que neles é como se ninguém no final das contas vencesse? Por que nos conceitos de autonomia e plenivalência de vozes em Dostoiévski é preciso incluir que ele cede diante das vozes, que de modo algum coincidem com suas convicções, e isso é ainda mais verdade em relação às convicções que ele gostaria de ter e que ele atribuiu a si? Por outro lado, por que as vozes que claramente gozam de sua compaixão (Sônia, Zóssima, Aliócha etc.) não aparentam convicções acabadas e em absoluto produzem uma impressão de vencedoras, talvez até para o desgosto de Dostoiévski? (LUNATCHÁRSKI, 1929, p. 202).

A resposta a essas questões está, segundo Lunatchárski, na desagregação tanto do mundo circundante de Dostoiévski, quanto de sua própria consciência. O resenhador passa, então, a revelar as circunstâncias da formação da personalidade de Dostoiévski, as quais seriam profundamente típicas da sua época e da cultura russa. A principal circunstância condicionadora seria a falta de correspondência entre o meio social russo - caracterizado pela falta de cultura, pela passividade e pela atmosfera opressiva - e a consciência superior que gradativamente se formou em determinados extratos da nobreza e depois entre a intelliguentsia raznotchínetz. Esse descompasso seria causador de conflitos em Aleksandr Púchkin, Vissarión Belínski ${ }^{16}$, Nikolai Gógol, Nikolai Tchernichévski ${ }^{17}$, Nikolai Nekrássov ${ }^{18}$, Liev Tosltói. Alguns deles foram condenados a trabalhos forçados e enfrentaram problemas físicos e psicológios decorrentes de privações materiais extremas. Por fim, Lunatchárski aborda a influência da religião ortodoxa na intelliguentsia russa do século XIX, que serviu, em graus variados, como ideal para resolver os graves conflitos sociais, econômicos e

\footnotetext{
${ }^{16}$ Vissarión Grigórievitch Belínski (1811-1848) escritor, tradutor e crítico literário, um dos representantes do fenômeno raznotchínetz. Foi ativista político a favor da libertação dos servos na Rússia czarista e integrante de Círculos Filosóficos dedicados à discussão da obra do filósofo alemão Georg Hegel.

${ }^{17}$ Nikolai Govrílovitch Tchernichévski (1828-1889) foi jornalista, escritor, filósofo materialista, revolucionário democrata e crítico do socialismo utópico. Seu romance mais conhecido, «O que fazer» (1863), influenciou os movimentos revolucionários na Rússia czarista.

${ }^{18}$ Nikolai Aleksiéevitch Nekrássov (1821-1878), de origem nobre, foi importante poeta, jornalista e editor chefe das revistas "Sovremiénik" e "Otiétchestvennie zániski". Suas ideias e obras são consideradas como parte de movimentos revolucionários na Rússia czarista.
} 
políticos da época. Lunatchárski considera que a religião condicionou o modo de pensar de Gógol, Tolstói e Dostoiévski em uma escala ascendente que partia, segundo ele, de uma visão ingênua em Gógol e atingiu um ideal de democracia e princípio ético na figura do Cristo em Dostoiévski. Após uma longa exposição da influência do meio social sobre Dostoiévski e seus contemporâneos, Lunatchárski retoma as teses de Bakhtin nos últimos parágrafos de sua longa resenha artigo:

\begin{abstract}
A meu ver, é preciso partir dessa compreensão sobre Dostoiévski para entender a profundidade real do polifonismo nos seus romances e novelas, asssinalado por $\mathrm{M}$. M. Bakhtin. Apenas a desagregação interior da consciência de Dostoiévski junto com a desagregação da jovem sociedade capitalista russa levaram-no à exigência constante de merecer o processo inicial do socialismo e da realidade, diante da qual o autor criou para esses processos as mais desfavoráveis condições em relação ao socialismo materialista.

$[\ldots]$

Aquela unidade artística superior que M. M. Bakhtin sente nas obras de Dostoiévski, mas não define e considera mesmo indefinível, é justamente essa falsificação delicada, sutil e temerosa de si própria, e com o tempo uma súbita falsificação grosseira e policialesca do processo, que ocorre em cada romance e em cada novela. Aquela liberdade inaudita de 'vozes' na polifonia de Dostoiévski, que impressiona o leitor, é precisamente o resultado em essência do fato de que o poder de Dostoiévski sobre os espíritos mobilizados por ele é limitada. (LUNATCHÁRSKI, 1929, p. 209).
\end{abstract}

O resenhador conclui que o polifonismo de Dostoiévski decorre de sua consciência, por um lado, dos graves conflitos da sociedade russa da época com sérias consequências para o bem estar material e espiritual da população, e, por outro, da sensação de limitação de sua ação jornalística e literária para resolver esses conflitos.

Ao comentar essa resenha, Botcharóv (2000) aponta três aspectos significativos: primeiramente, as apreciações de Lunatchárski terão influência sobre a reedição em 1963 de PPD, por exemplo quando Bakhtin retoma Shakespeare e Balzac; em segundo lugar, o próprio Bakhtin afirmou que a resenha-artigo de Lunatchárski desempenhou um papel importante na revisão de sua pena em 1929; e, por fim, apesar da importância de Lunatchárski na administração soviética, o tom positivo de sua resenha não conseguiu determinar a recepção do livro de Bakhtin à época.

A resenha de Lunatchárski destaca-se das anteriormente expostas por concentrar-se na natureza do conceito de polifonia, que, a meu ver, é um dos mais difíceis de serem compreendidos e empregados em análise. O resenhador vai buscar a solução para esse problema no conflito da intelliguentsia russa do século XIX, da qual fazia parte Dostoiévski, com o meio social circundante, muito embora percebamos, por meio de suas muitas ressalvas, as dificuldades de Lunatchárski em aceitar plenamente a tese de Bakhtin.

A quinta e última resenha saída em 1929 foi publicada sem assinatura, mas, conforme informações de Botcharóv e Miélikhova (2000), é da autoria de Gróssman-Róchin, também autor da terceira resenha acima analisada e cujo ponto de vista definiu a orientação do debate sobre o livro na União Soviética.

\title{
M. Bakhtin. - "Problemas da obra de Dostoiévski". \\ Priboi, 1929. 244 p. Preço 2 rublos 50 kopéikes ${ }^{19}$
}

No trabalho de Bakhtin sobre Dostoiévski, há muitas ideias interessantes e merecedoras de atenção. O autor corretamente se recusa a colar em Dostoiévski a etiqueta de "romântico". Isso é correto não só porque o "romantismo" e o "realismo" são termos em grande medida indefinidos, mas também porque o estilo e o gênero

\footnotetext{
${ }^{19}$ Publicada em Oktiábr [Outubro], Revista artístico literária e socio política, vol. 11, Moscou, 1929. p. 195-197.
} Tradução minha. 
de Dostoiévski exigem uma pesquisa específica. É verdade que a autoconsciência dos personagens desempenha um papel enorme na obra de Dostoiévski e é certo que a ideia-ideologia ocupa um lugar excepcional na obra, mas não encontramos uma resposta precisa a essa questão em Bakhtin. A "plurivocalidade" na obra de Dostoiévski é corretamente demonstrada, mas a questão não é resolvida. Parece-nos que é preciso ouvir uma única voz de classe no lugar da "plurivocalidade". Bakhtin aqui não ouve. Falemos de modo direto: o livro de Bakhtin é uma mistura de positivismo e de idealismo. Se o sociologismo aparece em Bakhtin, ele ocorre de um ponto de vista positivista; a avaliação é desprendida da gênese de classe. Bakhtin cita Kaus. Kaus sublinha que só o capitalismo aniquilou os limites entre os grupos sociais e gerou, mas não resolveu os problemas; só esse capitalismo pode servir de base da obra de Dostoiévski. Contudo, semelhante apontamento serve no melhor dos casos como pressuposto da análise. Quais grupos sociais são os "portadores” na obra de Dostoiévski? Quais são os leitmotifs de classe? Sobre isso nada sabemos em Bakhtin. Não é verdade que Dostoiévski parece inserir todo o mundo exterior na autoconsciência do personagem, de um modo que, para o personagem, não há nada de inesperado. Isso é incorreto, porque o caráter do romance de aventura, sobre o qual Bakhtin insiste, propõe de modo obrigatório justamente o inesperado. Isso é incorreto em um sentido profundo: a questão é que Dostoiévski e seus personagens são impotentes para desvendar até o fim as molas da existência social e são vítimas do "fetichismo". Não é acidental o fato de que Dostoiévski fala com a boca do personagem do subsolo sobre o caráter não cognoscível da história e sobre ao menos a falência da razão utilitária.

Fica totalmente sem atenção a questão sobre a mistura de uma dialética duvidosa e uma sofística inquestionável em Dostoiévski. Bakhtin não conseguiu em absoluto descobrir a gênese da obra de Dostoiévski. Mais do que isso: o autor fez tudo o que foi possível para orientar a pesquisa por um caminho falso, idealista e anticlassista (em um balanço final tudo é de classe). O mesmo ocorre com a afirmação de Bakhtin sobre os dois tipos de romance. O romance de costumes nos dá o tipo, a imagem, o caráter fortemente localizado. A peculiaridade do personagem é reservada a ele de modo mais ou menos sólido. O personagem do romance de costumes é predeterminado pela classe. Já no romance de aventura, vocês têm apenas um conjunto de possibilidades desconsideradas. Aqui o personagem e seu comportamento não são predeterminados pelo meio social. Permanece o fato de que Bakhtin não nos convenceu, que ele determina criativamente o meio social: Bakhtin rompe o contato com o solo social; o autor, intencionalmente ou não, abre a porta ao estudo da liberdade artística da vontade.

A seguinte citação não deixa nenhuma dúvida sobre a posição idealista de Bakhtin:

"O enredo de aventuras, ao contrário, é precisamente uma roupa que se ajusta bem ao personagem e que ele pode mudar o quanto quiser. $\mathrm{O}$ enredo de aventuras opera não com o fato de que o personagem existe e ocupa um lugar na vida, mas com o fato de que ele não existe e de que, do ponto de vista de uma realidade presente, ele não é predeterminado e inesperado. O enredo de aventura não opera com situações presentes e estáveis familiares, sociais, biográficas, ele se desenvolve contra elas. A situação de aventuras é aquela na qual pode se encontrar qualquer pessoa, tomada como ser humano. Além disso, o enredo de aventuras não utiliza qualquer localização social estável como forma que dá acabamento à vida, mas como "situação". Assim, o aristocrata do romance de bulevar não tem nada em comum com o aristocrata do romance socio-familiar. $\mathrm{O}$ aristocrata do romance de bulevar é uma situação na qual a pessoa se encontra. A pessoa age na roupagem do aristocrata, enquanto ser humano: atira, comete um crime, foge dos inimigos, supera obstáculos etc. Nesse sentido, o enredo de aventuras é profundamente humano. Todas as instituições sociais e culturais, corporações, classes e relações familiares são apenas situações, nas quais pessoas eternas e iguais podem encontrar-se. As tarefas ditadas pela natureza humana eterna, pela autopreservação, pela sede de vitória e triunfo, pela sede de possuir, pelo sentimento de amor, determinam o enredo de aventura".

O que significa a "natureza humana eterna"? Será que não é a reabilitação do racionalismo mecânico e metafísico? Contudo, se no seu tempo esse racionalismo foi progressista, agora o discurso sobre o homem eternamente igual a si próprio é reacionário, ainda mais que, na colocação de Bakhtin, esse homem igual pode ser combinado de modo semelhante com a metafisica autêntica. E talvez não seja grandiosa a afirmação de que a "natureza humana" vale acima das relações entre o latifundiário e o camponês, o proprietário e o proletariado. $\mathrm{Na}$ verdade, Bakhtin foi astuto... Preste atenção na lista de preço das "propriedades" pertencentes a essa pessoa eterna e célebre - da natureza humana eterna: autopreservação, a sede de vitória e de solenidade, a sede de possuir, o amor sensível. É uma lista de preços completamente notável! Talvez Bakhtin revele-nos o segredo de ao menos uma dessas "propriedades" da sede de possuir? Não entraria nessa sede não só o desejo de possuir o objeto do amor, mas também o de possuir ... os bens sagrados? Ou Bakhtin só opera com uma álgebra "eterna" e não deseja rebaixar a natureza eterna a uma pobre "aritmética"? Bakhtin não nos explica: tal sede de possuir no mundo terrestre e de classes também é elevada acima das relações entre o latifundiário e os camponeses, entre o proprietário e o proletário? Penso que o leitor está esclarecido não só do direcionamento, mas também da gênese do trabalho de Bakhtin.

$\mathrm{Na}$ Europa ocidental, não passa o fervor por Dostoiévski. Isso é compreensível. A existência desorganizada das classes intermediárias explica o crescimento da admiração por Dostoiévski. Entre nós ocorre a superação do dostoievismo não por meio da negação e da reprovação abstratas e infundadas, mas por meio do 
esclarecimento científico e do direcionamento da obra de Dostoiévski. O livro de M. Bakhtin é um passo para trás - o autor claramente nos arrasta para o pântano do idealismo. Falaremos separadamente sobre as observações individuais e positivas.

De modo semelhante à resenha anterior deste mesmo autor, seu foco é revelar o idealismo sob a aparência ou máscara de sociologismo. Para fundamentar essa opinião, o mesmo trecho de POD citado na resenha anterior é também aqui reproduzido, com o propósito de provar que Bakhtin opera com uma visão idealista dos personagens, cujas características "eternas" estão acima das determinações de classe. A resenha encerra apontando uma diferença na recepção da obra de Dostoiévski à época: na Europa ocidental, essa recepção é fervorosa, enquanto que na União Soviética ela é pautada por uma análise científica. Essa visão revela uma fase na recepção soviética da obra de Dostoiévski, que foi submetida a uma crítica marxista desqualificadora que reprovava obras como "Crime e Castigo" e "Os Demônios", por conterem críticas a ações revolucionárias por meio de luta armada e consequente sacrifício de vidas humanas, e aprovava obras como "Gente Pobre" e "Humilhados e Ofendidos", em razão da representação das condições socioeconômicas desfavoráveis de seus personagens.

A sexta resenha, "Idealismo plurivocal" (sobre o livro de M. M. Bakhtin "Problemas da obra de Dostoiévski" ${ }^{20}$ de M. Stárenkov tem o formato de um artigo de 12 páginas e, segundo Botcharóv e Miélikhova (2000), depois dela a crítica soviética não mais se pronunciará a respeito do livro. O título antecipa o viés interpretativo da resenha: Bakhtin realiza uma abordagem idealista da obra de Dostoiévski. Essa interpretação é bem grave e poderia ter condenado Bakhtin à morte, não fosse o fato de ele ter sido enviado para o exílio e, em seguida, permanecido na obscuridade até o final dos anos 1950. Devido a sua extensão, procederemos à exposição de sua organização geral e reprodução dos fragmentos mais ilustrativos, assim como fizemos com a resenha-artigo de Lunatchárski.

Primeiramente, Stárenkov caracteriza o diálogo polêmico de Bakhtin com a crítica da obra de Dostoiévski: "M. Bakhtin rechaça uma 'abordagem formalista estreita' e um ideologismo estreito, bem como não considera possível explicar a obra de Dostoiévski do ponto de vista monístico e dialético" (STÁRENKOV, 1930, p. 92). As duas primeiras afirmações fundam-se em proposições explícitas de Bakhtin, mas a terceira não é afirmada por este e sim atribuída a ele por Stárenkov.

Em seguida, o resenhista passa a avaliar o que seria a primeira tese de POD: "para a representação dos personagens de Dostoiévski, como nos afirma M. Bakhtin, 'servem não os traços da realidade, mas a significação desses traços para ele próprio, para sua autoconsciência"” (p. 54)" (STÁRENKOV, 1930, p. 93). Essa tese é criticada com base em uma citação da obra de Plekhânov, segundo a qual a literatura é condicionada pela realidade, princípio ao qual Bakhtin se oporia, por se recusar a reconhecer que a autoconsciência dos personagens depende e é uma parte da realidade. Segundo Stárenkov, a defesa de autossuficiência da consciência por Bakhtin suprimiria a posição social dos personagens: "M. Bakhtin tende a retirar a realidade dos personagens de Dostoiévski, ele leva a realidade a uma consciência fora da realidade, ao 'projeto' do autor e, com isso, ele tenta afirmar a consciência como critério da obra de Dostoiévski" (STÁRENKOV, 1930, p. 95). Stárenkov continua nessa direção para chegar à conclusão de que o personagem é, para Bakhtin, uma pura função da consciência do autor:

Os argumentos de uma função pura, como dominante artística, fora da realidade social, fora da causalidade e da gênese, esses são os conhecidos argumentos imanentes dos formalistas. Entretanto, nessa colocação dos 'problemas', Bakhtin rechaça a 'abordagem formalista estreita' e segue pelo caminho de um formalismo

${ }^{20}$ Publicada em "Literatura e Marxismo" (Revista de teoria e história da literatura), vol. 3, 1930. p. 92-105. 
largo. (STÁRENKOV, 1930, p. 96-97).

Passa-se naturalmente de uma função idealista pura do pesquisador para a palavra 'pura', 'voz pura'. Eis a conclusão dessas variações do 'projeto': 'O projeto do autor sobre o personagem é o projeto sobre a palavra. A palavra do autor sobre o personagem é a palavra sobre a palavra. Ela é orientada para o personagem, como para uma palavra, e por isso está dialogicamente voltada para ele. Em toda a construção do seu romance, o autor fala não sobre o personagem, mas com o personagem'. (p. 70) (STÁRENKOV, 1930, p. 96-97)

Além de idealista, agora a abordargem bakhtiniana é caracterizada como formalista. Contrariamente a essa posição, o resenhista afirma que a autoconsciência de heróis como Márkar Diévuchkin da novela "Gente pobre" é determinada pela realidade do pequeno funcionário público representada na obra de arte, ou seja, pela sua posição em um meio social, e a palavra é a função do organismo social, um fenômeno regrado pela existência concreta. E ainda: o projeto do autor não pode ser objeto de análises literárias, pois ele é o objeto da psicologia social e pode ser resolvido apenas com seus métodos científicos.

Dostoiévski:

A seguir, Stárenkov passa a tratar o modo como Bakhtin concebe a ideia nas obras de

\begin{abstract}
M. Bakhtin tenta mostrar que a ideia como objeto de representação tem 'princípios fundamentais', que 'extrapolam os limites de uma obra artística, eles são princípios de toda cultura ideológica do novo tempo'. Não iremos fazer uma excursão pela filosofia idealista, realizada por nosso pesquisador em busca de princípios ideológicos gerais. Entretanto, é preciso apontar o erro metodológico fundamental do pesquisador, ao não diferenciar a ideia encarnada no conceito lógico (filosofia) da ideia fixada nas imagens poéticas e tentar inutilmente igualar os princípios lógicos do enunciado-ideia com os princípios do enunciado-ideia nas obras literárias, esquecendo-se de que a literatura de ficção, enquanto um elemento ideológico geral, é ao mesmo tempo uma expressão específica daquela ideologia geral naquela estrutura imageticamente verbal. (STÁRENKOV, 1930, p. 100).
\end{abstract}

Em seu exame da abordagem de Bakhtin, o resenhador reafirma que a ideologia é uma realidade social conscientemente formulada e pertencente a diferentes classes, que a ideia bakhtiniana de "estratos profundos de caráter social" não tem relação alguma com a explicação marxista e que a ideologia não pode constituir a forma, pois ela é um ato de consciência e por isso não pode ser uma causa primeira.

Stárenkov finaliza a análise da primeira parte de POD ao tratar do enredo do romance de Dostoiévski, o qual Bakhtin aproxima dos romances de aventura e de bulevar. Segundo o resenhador, esse é o aspecto menos desenvolvido de POD e serve para repudiar os traços sociais concretos da obra ao mesmo tempo que a fundamenta na "natureza humana eterna", levando a conclusões inúteis.

A seguir, o resenhador analisa a segunda parte de POD dedicada à estilística de Dostoiévski e que ele considera mais minuciosa. No entanto, novamente aponta-se que a abordagem estilística de Bakhtin foge da realidade e do mundo objectual.

O último aspecto examinado é a tese sobre a polifonia dos romances de Dostoiévski, que o resenhador acusa de ser imprecisa, por utilizar uma terminologia inspirada no universo musical, ao invés de primar pela precisão científica, e em seguida classifica a tese da polifonia de empirismo baseado no fato de que "o pesquisador foi a uma sala de concerto, ouviu uma sonoridade plurivocal e não compreendeu a unidade dessa sonoridade" (STÁRENKOV, 1930, p. 105).

$\mathrm{O}$ autor encerra a resenha com a afirmação de Bakhtin sobre o caráter sociologicamente imanente da obra literária: "Se a obra é imanente, então ela não pode ser condicionada socialmente, se é sociológica, não pode ser internamente predeterminada e 
imanente" (STÁRENKOV, 1930, p. 105). Em síntese, o autor declara que Bakhtin tenta mascarar sua abordagem idealista com uma roupagem sociológica e que os teóricos da literatura marxistas devem combater esse tipo de trabalho: "A teoria da literatura marxista deve abrir fogo contra posições mascaradas do idealismo e vencer seus escudeiros". (STÁRENKOV, 1930, p. 105).

\section{POD e a crítica no exterior}

Nesta seção, examinaremos parte da recepção de POD fora da União Soviética, constituída por uma resenha, duas menções em livros dedicados a Dostoiévski e uma análise extensa de POD em livro também dedicado à análise da obra de Dostoiévski.

M. Bitsílli ${ }^{21}$ (Odessa, 1879-Sofia, 1953) foi historiador, filólogo e crítico literário. Em 1917, defendeu, na Universidade de Petrogrado, uma tese em que abordou as diferenças entre a personalidade do homem no Renascimento e na Idade Média. Em 1920, emigrou para a Sérvia, onde, de 1924 a 1948, foi professor no Departamento de História Moderna da Universidade de Sofia. Mesmo do exterior, Bitsílli acompanhava atentamente o desenvolvimento da literatura e crítica literária russa, tendo organizado coletâneas e resenhado obras de autores russos como Tchékhov, Gógol, Púchkin, Tolstói e Dostoiévski.

No ano seguinte à publicação de POD, Bitsílli publicou uma pequena resenha sobre esse livro no periódico Sovremiénnie zápiski [Notas contemporânas] (Paris, vol. 42, 1930, p. 538-540), em que se concentra a descrever as teses principais da obra de Bakhtin e fazer breves comentários críticos, no geral, positivos. Essa resenha é interessante, pois mostra que POD de Bakhtin chamou a atenção de estudiosos da literatura e da crítica literária russa que moravam fora da União Soviética e que julgaram a obra digna de ser resenhada e comentada. Em outros termos, o livro de Bakhtin sobre Dostoiévski já em sua edição de 1929 não foi um acontecimento bibliográfico sem repercussão, mas suas teses inovadoras foram reconhecidas e avaliadas logo após o seu lançamento.

\section{M.M. Bakhtin. Problemas da obra de Dostoiévski. Leningrado, 1929. ${ }^{22}$}

A principal tese de Bakhtin é a seguinte: o romance de Dostoiévski é uma categoria completamente nova e particular da palavra artística. Não se trata de um romance no sentido geralmente aceito da palavra, romance socio-psicológico, no qual tudo é objetificado, tudo é representado sob o ângulo de visão do autor; não se trata tampouco de um "romance tragédia", como o designou Viatchesláv Ivánov, pois em uma obra dramática tudo está subordinado à unidade do estilo autoral. Dostoiévski tende à máxima concretização possível dos seus personagens, e isso significa que eles não são objetos da percepção autoral, como no geral em todos os romancistas, mas sujeitos no sentido pleno dessa palavra. ${ }^{*}$ Normalmente o romancista coloca os próprios personagens no mundo dele; já Dostoiévski afasta-se de si: em seus romances o mundo é mostrado do ponto de vista de cada um dos personagens; há tantos mundos e estilos, quantos indivíduos agentes. Em qualquer romance "monológico" ou "homofônico", tudo está subordinado a uma voz, a do autor; o romance de Dostoiévski é "polifônico". Em Dostoiévski, nunca há só uma única voz, mesmo em seus numerosos monólogos e confissões. Quando o "homem do Subsolo" ou o marido de "Uma criatura dócil" falam consigo próprios, ouvimos claramente duas vozes: a do falante e a do seu interlocutor representado, mesmo que isso fosse outro "eu". Quando dois conversam, a multivocalidade imediatamente cresce, pois cada falante põe-se à escuta da "segunda" voz do seu interlocutor, àquilo que, sem palavras, é advinhado sob as palavras pronunciadas. A multiplicidade de estilos e de planos dos romances de Dostoiévski foi observada ainda antes. Normalmente isso é colocado em relação com o pensamento dialético de Dostoiévski. Contudo, não há relação

\footnotetext{
${ }^{21}$ Fonte: http://odessa-memory.info/index.php?id=298. Acesso em 27 jun. 2018.

22 Tradução minha.

* O artigo de D. Tchijiévski pode servir como um comentário excelente a essa tese: "K probliéme Dvóinika" [Sobre o problema do duplo] na coletânea O Dostoiévskom [Sobre Dostoiévski], organizada por A. L. Bem (Praga, 1929).
} 
artística dialética nos romances de Dostoiévski. A dialética pressupõe evolução, desenvolvimento no tempo. Já Dostoiévski percebe o mundo, por assim dizer, fora e acima do tempo, apenas no espaço. Nele, tudo já é dado desde o princípio. Em razão disso - novamente de um ponto de vista puramente artístico - nele não pode haver uma subordinação de planos e estilos diversos, que correspondam a aspectos dialéticos diversos de uma Ideia: na vida real os aspectos da Ideia revelam-se no processo real de evolução no tempo; a representação da vida fora do tempo é portanto adialética. Nesse caso, em que consiste a unidade artística dos romances de Dostoiévski? Bakhtin compara a obra de Dostoiévski com a de Dante: só em Dante há uma tal riqueza de "vozes". Observo que Benedetto Crocce nega a unidade poética da Divina Comédia. Segundo Crocce (La Poesia di Dante), há "poeticidade" na Comédia apenas em lugares isolados, não em seu todo. A ideia geral da Comédia não recebeu em Dante sua encarnação simbólica. Aquela unidade do plano da Comédia, que habitualmente admira-se, fica fora da poesia. Em seu todo, a Comédia não é simbólica, mas alegórica. Diferentemente do simbólico, a alegoria não nasce junto com a ideia, mas é anexada a ela. Bakhtin não afirma o mesmo sobre os romances de Dostoiévski? O domínio do princípio da multivocalidade por si só ainda não cria a unidade artística do romance filosófico, assim como se dá com o romance de Dostoiévski. As relações - ou não - dos elementos artísticos de Os irmãos Karamázov, Os Demônios, O Idiota com a filosofia de Dostoiévski são necessárias para o nexo interior? Esses romances nasceram - ou não - juntamente com essa filosofia em um ato criativo único? Eis a questão, à qual a pesquisa de Bakhtin se aproxima de modo formidável pela sutileza, aliás considerando tudo o que até aquele momento tinha sido pesquisado sobre Dostoiévski, e para a qual ela não fornece uma resposta. A meu ver, a resolução dessa questão deve partir das teses que estão solidamente consolidadas na pesquisa de Bakhtin. Esclarecerei com um exemplo que mostra para qual direção é preciso movimentar-se. Não há dúvida de que, em nossa consciência, a filosofia de Ivan Karamázov não pode ser apartada da legenda sobre o grande Inquisitor. "Transposta" para outras palavras, ela deixa assim de ser "aquela mesma" filosofia (Bakhtin explica maravilhosamente a tendência de Dostoiévski para a concretização de ideias, sua luta contra o formalismo kantiano): não há ideia "no geral", toda ideia soa em um outro sentido (na acepção plena dessa palavra) a depender de quem a enuncia. Contudo, isso ainda não é tudo. Isolemos a "voz" de Ivan Karamázov do coro das outras "vozes", que soam em Os irmãos Karamázov, e ele próprio já soará de modo diferente. No plano artístico isso corresponde a quê? Por que não podemos imaginar Ivan Karamázov sem Dmítri, sem Aliócha, sem Fiódr Pávlovitch, sem Smierdiákov etc.? Como e por que se chega a uma consonância a partir de uma multiplicidade de vozes, como e por que surge um certo estilo geral da reunião dos mais variados estilos - eis no que consiste o problema estético, colocado na pesquisa da obra de Dostoiévski. No próprio Bakhtin, encontramos a chave da sua solução: na sua observação sobre a "atemporalidade" da percepção do mundo em Dostoiévski. Contudo, essa percepção não é menos "real", do que nosso "normal". Essa é a percepção da vida no sonho. A. L. Bem [ver seu artigo Dramatizátsiiia briéda (A dramatização do delírio) na coletânea acima mencionada] mostrou que a ação de "A proprietária" não é outra coisa que um "delírio dramatizado". Seria preciso mostrar o mesmo, no que diz respeito ao objetivo imediato da pesquisa estética da obra de Dostoiévski, para os outros trabalhos dele.

O tom da resenha de Bitsílli é bem diferente daquele dos resenhadores soviéticos. As teses e as soluções encontradas por Bakhtin são aprovadas e reafirmadas pelo resenhador, que demonstra conhecer a crítica russa sobre Dostoiévski. A tese de Bakhtin sobre a polifonia é apresentada em contraponto à conhecida análise de Viatcheslav Ivánov $(1909,1916)$ sobre o romance tragédia, que, segundo Botcharóv e Miélikhova (2000), é uma das fontes importantes do livro de Bakhtin. Vejamos um fragmento que, ao mesmo tempo, revela o teor da tese de Ivánov e uma das origens do pensamento bakhtiniano:

Semelhantemente à criação de uma sinfonia, ele utilizou o seu mecanismo na arquitetônica da tragédia e aplicou no romance o método correspondente ao desenvolvimento temático e contrapuntístico na música, desenvolvimento com o qual o compositor [...] nos leva para a percepção da vivência psicológica de toda a obra enquanto unidade. (IVÁNOV, 1916, p. 20)

A metáfora musical e o conceito de arquitetônica tão caros à abordagem bakhtiniana já estão claramente colocados no texto de Ivánov, portanto, diferentemente da oposição estabelecida por Bitsílli, concordamos com Botcharóv e Miélikhova de que o trabalho de Ivánov ressoa no de Bakhtin.

Um segundo aspecto da resenha de Bitsílli é sua avaliação sobre a "“atemporalidade' da percepção do mundo em Dostoiévski” como o ponto de vista artístico descoberto por 
Bakhtin para descrever e explicar a consonância de vozes no romancista russo. Em consequência disso, Bitsílli argumenta que há impossibilidade de uma relação artística dialética, pois esta pressupõe evolução no tempo. Essa avaliação lança luz sobre a distinção entre dialogismo (consonância de vozes em sua simultaneidade no espaço) e a dialética (evolução e desenvolvimento no tempo). Por fim, destaco que Bitsílli faz uma crítica central: "Esses romances nasceram - ou não - juntamente com essa filosofia em um ato criativo único? Eis a questão, à qual a pesquisa de Bakhtin se aproxima de modo formidável pela sutileza [...] e para a qual a pesquisa não fornece uma resposta." (1929, p. 637). Na avaliação de Bitsílli, embora a pesquisa de Bakhtin tenha contribuições sofisticadas para a compreensão da obra de Dostoiévski, ele não traz uma resposta sobre a relação entre a unidade artística e a filosofia de Dostoiévski. Botcharóv e Miélikhova (2000) relatam que Bitsílli não deixará de lembrar de POD em trabalhos posteriores sobre Dostoiévski.

POD é ainda citado em artigos das coletâneas organizadas por A. L. Bem (1933) nos anos 1930, em Praga. No artigo de Lapchín (1933), que foi professor de Bakhtin, antes da revolução, no departamento de filosofia da Universidade de São Petersburgo (BOTCHARÓV, MIÉLIKHOVA, 2000), POD é mencionado no seguinte excerto:

\begin{abstract}
Nas obras de Dostoiévski, junto com paródias no sentido estrito da palavra estão abundantemente espalhados elementos de parodismo parcial. M. M. Bakhtin submete o estilo parodístico a uma análise linguística excelente e assinala em Dostoiévski seus traços característicos. Ele aponta que nas paródias ocorre uma intermitência constante entre a significação primeira da palavra - seu conteúdo intencional direcionado para o sentido - e um sentido outro em contradição com o primeiro. O efeito cômico é obtido mediante essa bivocalidade sem fim da narração. (LAPCHÍN, 1933, p. 40-41)
\end{abstract}

No prefácio de Bem a respeito das fontes da obra de Dostoiévski, cita-se POD no fragmento:

Lá onde consegue-se estabelecer aspectos puramente formais de semelhança, eles são importantes como indicadores desse subsolo de ideias artísticas mais profundo, no qual cresceu a obra. A 'polêmica criativa' é o conceito sob o qual, até certa medida, pode ser conduzida a obra de Dostoiévski. A enorme importância organizadora dessa 'orientação polêmica' das obras de Dostoiévski foi mostrada maravilhosamente por M. M. Bakhtin em seu livro 'Problemas da obra de Dostoiévski' (Leningrado, 1929). (BEM, 1936, p. 8)

Em ambos os casos, as análises realizadas por Bakhtin são muito bem avaliadas e demonstram sua repercussão positiva entre especialistas da obra de Dostoiévski. O quarto e último trabalho fora da União Soviética por nós encontrado é a análise de Vassíli Leonídovitch Komaróvitch (1894 Níjnii Novgorod -1942 Leningrado), teórico da literatura russo que, assim como Bakhtin, foi condenado ao exílio no final de 1928, por participação em um Círculo de intelectuais. Em um ampla revisão sobre Dostoiévski publicada na Alemanha e traduzida parcialmente para o russo por Vitáli Mákhlin em 1995, Komaróvitch analisa e rejeita praticamente todas as teses de POD. Em razão de limites de espaço, faremos um breve elenco das críticas desenvolvidas por Komaróvitch:

1) Bakhtin defende a criação do romance polifônico com base em novelas de Dostoiévski ("Gente pobre", "Memórias do subsolo", "Uma criatura dócil"), mas, para ser coerente, deveria operar apenas com seus 5 grandes romances; 2) Bakhtin não explica a quantidade nem as funções particulares que a confissão, um gênero literário tradicional, desempenha nos romances de Dostoiévski, bem como exagera o peso da autoconsciência expressa na voz dos personagens; 3) Para Bakhtin, a ideia em Dostoiévski está ligada à palavra do personagem sobre si próprio e está livre da avaliação do autor. Contudo, segundo Komaróvitch, o personagem e a ideia conservam seu acabamento final na esfera da catástrofe, 
aspecto a que Bakhtin não prestou atenção; 4) A análise contida em "O discurso em Dostoiévski" "opera com um material arbitrariamente utilizado e não corresponde à hierarquia factual da variedade estilística do discurso nos grandes romances de Dostoiévski" (Komaróvitch, 1995, p. 81); 5) Bakhtin não fornece um fundamento sólido para a existência do romance polifônico e isso porque ele o procura no próprio Dostoiévski e não na poética histórica.

Komaróvitch é citado em POD como empreendendo uma análise "puramente monológica" (BAKHTIN, 1929, p. 32) da unidade do romance de Dostoiévski, o que explica, em grande parte, as críticas dos itens 2 e 3, pois os dois autores compreenderam a obra do romancista russo de pontos de vista bem distintos. A crítica à utilização de novelas para defender uma tese sobre o romance me parece pertinente; já a crítica sobre a análise estilística (item 4) não condiz com a riqueza e a sutileza das análises bakhtinianas, enquanto que a ausência de uma poética histórica, admitida pelo próprio Bakhtin no prefácio de POD e apontada por outros resenhadores, motivará a principal alteração na segunda edição de 1963 com a ampliação do capítulo sobre os antecedentes históricos do gênero romanesco.

\section{Conclusões}

A tradução e o exame de resenhas soviéticas e no exterior de POD apontaram caminhos de leitura esclarecedores:

1) O tom dominante da crítica soviética a respeito de POD foi "desmascarar" a filosofia idealista sob uma roupagem sociológica. A exceção é a resenha de Arkádi Glagólev, que considera correta e legítima a abordagem sociológica desenvolvida em POD. Os editores contemporâneos reforçam a presença da filosofia idealista em Bakhtin: Boniétskaia $(2017 \mathrm{a} / \mathrm{b})$ afirma a influência de filósofos idealistas e religiosos russos, e Botcharóv, nos comentários ao volume II das "M.M. Bakhtin. Obras reunidas", considera que Bakhtin adotou uma abordagem sociológica apenas como uma roupagem, para que a obra fosse aceita pela crítica dominante à época. É bom lembrar que, segundo a nota jornal Jizn isskústva [Vida da arte], de 22 a 28 de agosto de 1922, Bakhtin trabalhou em POD simultaneamente aos seus textos filosóficos do início dos anos 1920. Nesse contexto, Bakhtin parece ter adaptado seu texto em função do horizonte valorativo da União Soviética dos anos 1920, em que o marxismo em sua interpretação sociológica é a filosofia dominante e uma orientação a ser seguida por todas as ciências humanas;

2) A segunda parte de POD, que corresponde ao capítulo "O discurso em Dostoiévski" de PPD, foi muito melhor recebida pela crítica do que os demais capítulos, com a exceção da resenha de Komaróvitch, que, a meu ver, faz uma avaliação bem pouco fundamentada a esse respeito;

3) Lunatchárski e Stárenkov assinalam que o autor de POD realiza uma pesquisa formal dos procedimentos de criação de Dostoiévski, com incursões no campo da elucidação sociológica. Aqui e no item anterior, o fundo aperceptível de percepção de parte dos destinatários de POD, em razão da teoria formalista russa e soviética recém desenvolvida, está pronto a reconhecer e a acolher análises formais bem fundamentadas;

4) A crítica de Arkádi Glagólev e Vassíli Komaróvitch a respeito da ausência de uma abordagem histórica do romance polifônico de Dostoiévski assinala aquele aspecto que motivará a maior alteração na segunda edição em 1963, quando Bakhtin inclui, no penúltimo capítulo, as questões de poética histórica. A pesquisa sobre poética histórica estará no centro da atenção de Bakhtin durante toda a década de 1930, quando ele escreve seus trabalhos sobre o gênero romance e sobre a obra de François Rabelais;

5) A tese sobre a polifonia dos romances de Dostoiévski é o ponto mais polêmico na recepção de POD: por um lado, ela é rejeitada por Berkóvski, Stárenkov e Komaróvitch que 
defendem o papel unificador do autor; por outro, Lunatchárski, de um ponto de vista sociológico, e Bitsílli, de uma perspectiva da unidade poética, acolhem a tese, com ressalvas sobre o seu modo de constituição.

\section{Referências}

Bakhtin, M. M. Probliémi tvórtchestva Dostoiévskogo. [Problemas da obra de Dostoiévski]. Leningrado: Priboi, 1929.

Bakhtin, M. M. Bakhtin Sobránie Sotchiniénii [M.M. Bakhtin obras reunidas]. Vol. 2. Moscou: Rússkie slovarí, 2000. [Organizadores. S. G. Botcharóv, L. S. Melikhóva]

Bakhtin, M. M. Probliémi poetiki Dostoiévskogo [Problemas da poética de Dostoiévski]. Moscou: Ed. “Э”, 2017a.

Bakhtin, M. M. Izbrannoe tom I. Ávtor i guerói v estetítcheskom sobítii. [Seleção vol. I O autor e o personagem no acontecimento estético]. Moscou-São Petersburgo: Tsentr gumanitárnikh initsiatív, $2017 \mathrm{~b}$.

Bakhtin, M. M. Izbrannoe tom II. Poétika Dostoiévskogo [Seleção vol. II A poética de Dostoiévski]. Moscou-São Petersburgo: Tsentr gumanitárnikh initsiatív, 2017.

Bem, A. L. (ORG.) O Dostoiévskom vol. 2. Praga,1933, p. 4-5.

Bem, A. L. O Dostoiévskom vol. 3. Praga, 1933, p. 4-5.

Bem, A. L. Predislóvie [Prefácio]. U istókov tvórtchestva Dostoiévskogo [Nas fontes da obra de Dostoiévski). Praga, 1936. p. 5-9.

Bakhtin, M.M. Teoria do romance I. A estilística. Tradução de Paulo Bezerra. São Paulo: ED34, 2015.

Bakhtin, M.M. Os gêneros do discurso. Tradução de Paulo Bezerra. São Paulo: ED34, 2016.

Berkóvski, N. M. M. Bakhtin. Probliémi Tvórtchestgo Dostoiévskogo (Problemas da Obra de Dostoiévski), 1929, L., Priboi. Mir, sazdaváemii literatúpoi (O mundo criado pela literatura). Moscou: Soviétski pissátel, 1989[1929]. p. 119-121.

Bitsílli, P. M. M. M. Bakhtin. Probliémi Tvórtchestgo Dostoiévskogo (Problemas da Obra de Dostoiévski), Leningrado, 1929. Ízbrannye trudi po filológuii (Trabalhos selecionados sobre filologia). Moscou: Nasliédie, 1996[1930], p. 636-638

Boniétskaia, N. Jízni i filossófskaia idiéia Mikhaíla Bakhtiná [Vida e ideia filosófica de Mikhail Bakhtin]. In: Bakhtin, M.M. Ízbrannoe tom I. Ávtor i guerói v estetítcheskom sobítii [Seleção vol. I O autor e o personagem no acontecimento estético]. Moscou-São Petersburgo: Tsentr gumanitárnikh initsiatív, 2017a, p. 5-41.

Boniétskaia, N. Tema Dostoiévskogo v trudákh M.M. Bakhtiná [O tema de Dostoiévski nos trabalhos de M. M. Bakhtin]. In: Bakhtin, M.M. Ízbrannoe tom II. Poétika Dostoiévskogo 
[Seleção vol. II A poética de Dostoiévski]. Moscou-São Petersburgo: Tsentr gumanitárnikh initsiatív, 2017b. p. 5-12.

Botcharóv, S. Predslóvie. Kommentárii. Probliémi poétiki Dostoiévskogo. [Prefácio. Comentários. Problemas da Poética de Dostoiévski]. In: Bakhtin, M. M. Probliémi poétiki Dostoiévskogo [Problemas da poética de Dostoiévski]. Moscou: Ed. “Э”, 2017. p. 7-8, 594638.

Botcharóv, S.; Miélikhova, L. Komentárii. In: Bakhtin, M. M. M. M. Bakhtin Sobránie Sotchiniénii [M.M. Bakhtin obras reunidas]. Vol. 2. Moscou: Rússkie slovarí, 2000. p. 428797.

Dolínin, A. C. (Org.) F. M. Dostoiévski. Statií e materiáli. São Petersburgo: Mysl, 1922.

Glagólev, A. Novo livro sobre F. Dostoiévski, Utchílelskaia Gaziéta, no. 91, p. 5, Moscou, 8 ag. de 1929.

Gróssman, L. Poétika Dostoiévskogo. Moscou: Gossudárstvennaia Akadémiia Khudójestvennykh Naúk, 1925.

Gróssman-Róchin, I. O sotsiologuízme M. M. Bakhtin, avtora "Probliémi Tvórtchesva Dostoiévskogo" [Sobre o sociologismo de M. M. Bakhtin, autor de "Problemas da Obra de Dostoiévski'”], Na literatúrnom postú, no. 18, Moscou, set. 1929, p. 5-10.

Gróssman-Róchin, I. M. Bakhtin «Probliémi tvórtchestva Dostoiévskogo», Oktiábr [Outubro], Revista artísticoliterária e sociopolítica, vol. 11, Moscou, 1929, p. 195-197.

Ivánov, V. Po zvezdám: statií i aforízmi [Pelas estrelas: artigos e aforismos]. São Petersburgo: Ory, 1909.

Ivánov, V. Borozdi e Miéji. [Sulcos/cissuras e limites] Ópiti estetítcheskie i kritítcheskie. [Ensaios estéticos e críticos] Moscou: Мусагет, 1916.

Jizn Isskústva [Vida da arte], no. 33, 22 a 28 de agosto de 1922, p. 4.

Komaróvitch, V. L. Nóvie probliémi izutchiéniia Dostoiévskogo 1925-1930. [Novos problemas do estudo de Dostoiévski 1925-1930]. In: Iortchenko, T. G. (Org.) M. M. Bakhtin v ziérkole krítiki [M. M. Bakhtin no espelho da crítica]. Tradução de V. L. Makhlin. Moscou: Labirint, 1995, p. 74-92.

Lapchín, I. I. Komítcheskoe v proizvediéniiakh Dostoiévskogo [O cômico em obras de Dostoiévski]. In: Bem, A. L. (Org.) O Dostoiévskom Vol.2. Praga: 1933, p. 31-50.

Lunatchárski, A. V. O mnogogólonosti Dostoiévskogo [Sobre a multivocalidade de Dostoiévski], Nóvii mir, n. 10, Moscou, 1929, p. 195-209.

Medviédev, P. N. O método formal nos estudos literários. Introdução crítica a uma poética sociológica. Tradução de S. C. Grillo e E. V. Américo. São Paulo: Contexto, 2012.

Pospelov, G. Preuvelitchiéniiia ot uvletchiéniia, Vopróssi literatúri, n. 1, Moscou, 1965, p. 95-108. 
Stárenkov, M. Mnogogólossii idealízm [Idealismo plurivocal], Literatura e Marxismo (Revista de teoria e história da literatura), vol. 3, Moscou, 1930, p. 92-105.

Volóchinov, V. N. Marxismo e filosofia da linguagem. Problemas fundamentais do método sociológico na ciência da linguagem. Tradução de S. Grillo e E. V. Américo. São Paulo: ED34, 2018 [1929].

Recebido em: 30 de julho de 2019 Aceito em: 07 de novembro de 2019

Publicado em: Dezembro de 2019 